\section{Integration of GC-MS in identification of possible final metabolites from phytase production in Pichia Pastoris based on sorbitol induction optimization}

\author{
Ndayambaje Jean Bernard ${ }^{1 *}$, Habarurema Gratien1, Habinshuti \\ Janvier ${ }^{1}$, Ingabire Angelique ${ }^{2}$, Ingabire Ange Sabine ${ }^{1}$, Martin \\ Patrick Ongol ${ }^{1}$ and S Meenakshisundaram ${ }^{3}$ \\ ${ }^{1}$ Department of Chemistry, University of Rwanda-College of Science and Technology, Avenue de \\ l'Armee, B.P. 3900, Kigali, Rwanda \\ ${ }^{2}$ Rwanda Agricultural and Animal resources Board, P. O Box 5016. Rubona, Huye, Rwanda \\ ${ }^{3}$ Anna University, Chennai, 600025 India
}

\section{Abstract}

The isolation of phytase using Pichia Pastoris under methanol/sorbitol co-feeding induction technique was investigated. The biological activity of extracellular phytase after optimization with co-substrates induction in 4 liters fermentor (NBS) increased to $13250 \mathrm{U} / \mathrm{ml}$. This led to a 509 fold increases in comparison to the other type of phytase. This effect was studied via induction with sorbitol/methanol in fermentation by Pichia pastoris GS115 (Mut $\left.{ }^{+}\right)$at $20^{\circ} \mathrm{C}$. The interference of by products; methylal, hexamine and (S)-(+)-1,2-propanediol with release of phytase in Pichia pastoris under methanol induction were detected and cannot be repressed by methanol induction alone. The TLC was used for glycerin analysis under methanol/sorbitol induction and the results were lesser compare to that obtained during phytase production under methanol induction alone. This work showed the higher expression of heterologous proteins and by fed batch fermentation; the expression identified an advantage of producing a significant activity of phytase.

\section{Practical applications}

Plant derived products including sorbitol have been used as alternative medicines for the therapeutic treatment of various diseases, food supplements and could be used in many manufacturing processes. It serves as a culture media for bacteria, and helps to distinguish the pathogenic $E$. coli $\mathrm{O} 157: \mathrm{H} 7$ from its most other strains. Cells growing on methanol require high oxygen consumption. Sorbitol was used as an alternative cheap co-feeding for the production of proteins and is a non-repressing carbon source for $A O X 1$ promoter with no effect on the level of $r$-protein at its induction phase. This report describes the isolation of phytase using Pichia Pastoris under methanol/sorbitol co-feeding induction techniques, and sorbitol showed to be a promising co-substrate, as it could enhance both cell growth and targeted protein productivity. This cofeeding and fed-batch induction technique was used for recombinant phytase production in a small and large scale production and the metabolites were analyzed.

\section{More Information}

*Address for Correspondence: Ndayambaje Jean Bernard, Department of Chemistry, University of Rwanda-College of Science and Technology, Avenue de l'Armee, B.P. 3900, Kigali, Rwanda,

Email: ndayambajejbk999@gmail.com

Submitted: March 26, 2021

Approved: April 09, 2021

Published: April 12, 2021

How to cite this article: Bernard NJ, Gratien $\mathrm{H}$, Janvier $\mathrm{H}$, Angelique I, Sabine IA, et al. Integration of GC-MS in identification of possible final metabolites from phytase production in Pichia Pastoris based on sorbitol induction optimization. Arch Biotechnol Biomed. 2021; 5 : 020-025.

DOI: 10.29328/journal.abb.1001024

Copyright: @ 2021 Bernard NJ, et al. This is an open access article distributed under the Creative Commons Attribution License, which permits unrestricted use, distribution, and reproduction in any medium, provided the original work is properly cited.

Keywords: Pichia pastoris; Sorbitol/Methanol co-feeding; Fermentation; GC-MS; Metabolites

Check for updates

OPEN ACCESS

\section{Introduction}

Sorbitol an isomer of mannitol can be isolated from the conversion of the carbonyl group of glucose to a hydroxyl group via the reduction reaction. This change allows the latter compound to be a carbohydrate classified as a polyol [1]. Sorbitol as a monosaccharide has four calories per gram and studies showed that it is a non-metabolite, since it is metabolically more inert than other saccharides [2,3]. It finds many applications in many manufacturing processes, as a pharmaceutical aid, toothpaste, sugar crystallization inhibitor and a dietary supplement [4]. In biotechnology, it is useful as a culture media for bacteria and allows to distinguish the pathogenic Escherichia coli 0157:H7 from most other strains 
of E. coli [5]. In nature, sorbitol is dominantly found in various plants including algae and higher plants. For methanol induction alone is a high degree reductant releasing a larger amount of energy in form heat [6], and the process undergoes a significant effect upon a methanol induction phase at large scale. Cells growing on methanol, brings technological challenges as it requires high oxygen consumption, and the demand for safety precautions due to the use of a flammable and toxicity substrate [7]. Recent studies revealed that the use of methanol was cheap and common substrate at the time the P. Pastoris system was introduced [5,8]. Nowadays, sorbitol is an alternative available cheap co-feeding for the production of proteins and is a non-repressing carbon source for $A O X 1$ promoter as it does not affect the expression level of $r$-protein at its induction phase $(1,2,4,11)$. Many processes of fermentation leading to the production of protein using $P$. Pastoris can be performed at an optimum induction temperature of $30{ }^{\circ} \mathrm{C}$, which is a suitable condition for cell growth. Other studies showed that sorbitol co-feeding techniques through the induction phase is less critical than with the mixture of feeds of glycerol and methanol $[7,9,10]$. The process seems to be favorable to the extent that carbohydrate metabolism may play a viable role in defining source-sink relations, regulating carbon partitioning among developing tissues, and ultimately determining cell growth [8]. The process of fed-batch fermentation is carried out in order to produce high-density cultivation. Naturally, in the latter procedure, a growth limiting substrate is fed to the reactor at a constant rate in the batch media. This may be after the depletion of substrate such as glycerol. This procedure is simple and very broadly used to get high cell density cultivation $[11,12]$. The de-repression of the AOX1 promoter allows cells to be ready for the induction process $[13,14]$ and after this phase, the methanol feeding could be performed to induce the AOX1 promoter. In a bioreactor the residue of methanol concentration is influenced by the methanol feeding quantity and control techniques, which is a specific growth rate for the culture media and the level of the expression of protein $[15,16]$. Recently, co-feeding of glycerol and methanol was performed showing a slow decrease in the glycerol feeding while methanol feeding was increased. The mixture of glycerol and methanol allows both a quick induction process of alcohol oxidase and adaptation of cellular metabolism which is higher than those with methanol feeding process $[17,18]$.

Methanol is able to be used as a source of carbon along with an inducer of recombinant protein expression. P. pastoris, in contrast, seems to intoxicate itself with metabolites (formic acid, formaldehyde) in the presence of high concentrations of methanol, which has a high substrate affinity for alcohol oxidase [19]. As a result, methanol prevents the development of the organism at high concentrations.

Generally, the common methanol feeding technique allows a constant specific growth-rate feeding ( $\mu$-stat), constant methanol concentration feeding, constant DO-based feeding
(DO-stat) and temperature-limited fed-batch (TLFB) $[10,20]$. The culture on methanol was cheap but it increases the cost of the process and limiting the cultivation capacity at high scale. The most promising co-substrate is sorbitol; which can be used in multi-carbon substrate mixture to replace pure methanol, as it could enhance both cell growth and targeted protein productivity. This study focuses on a sorbitol/methanol cofeeding and a fed-batch induction technique which is used for recombinant phytase production in a small and large scale production and the metabolites were analyzed.

\section{Material and methods}

\section{Growth of a P. Pastoris GS115-pPICZaA-phytase}

The prepared medium of YPD containing $20 \mathrm{~g} / \mathrm{l}$ of peptone, $10 \mathrm{~g} / \mathrm{l}$ of yeast extract, $20 \mathrm{~g} / \mathrm{l}$ of glucose, $20 \mathrm{~g} / \mathrm{l}$ of agar and $0.1 \mathrm{~g} / \mathrm{l}$ of Zeocin were utilized for the strain P. pastoris GS115 growth that was transformed with recombinant pPICZ $\alpha \mathrm{A}$ phytase in presence of $A O X 1$ promoter and incubated at 30 ${ }^{\circ} \mathrm{C}$ during 48 hours. In addition, a colony was inoculated into a volume of $5 \mathrm{ml}$ YPD liquid medium containing Zeocin $(100 \mu \mathrm{g} /$ $\mathrm{ml}$ ), and grown via shaking at $250 \mathrm{rpm}$ at $30^{\circ} \mathrm{C}$ overnight. The culture of seed was then inoculated into the medium of BMGY containing $10 \mathrm{~g} / \mathrm{l}$ of yeast extract, $20 \mathrm{~g} / \mathrm{l}$ of peptone, $13.4 \mathrm{~g} / \mathrm{l}$ of YNB, $4 \times 10^{-5} \mathrm{~g} / \mathrm{l}$ of biotin, $10 \mathrm{~g} / \mathrm{l}$ of glycerol and a solution of $0.1 \mathrm{M}$ of potassium phosphate buffer whose is $\mathrm{pH}$ 6.0.

\section{Phytase kinetic}

The kinetic determination of phytase was performed using various concentrations of the substrate of ranging from 0.2 to $5 \mathrm{mM}$ in $10 \mathrm{mM}$ of the solution of Tris- $\mathrm{HCl}$ buffer solution; $\mathrm{pH} 7.5$ with $\mathrm{CaCl}_{2}(1 \mathrm{mM})$. This process was followed by the measurement of the optimal $\mathrm{pH}$ of the activity of the enzyme utilizing a $25 \mathrm{mM}$ solution of glycine- $\mathrm{HCl}$; $\mathrm{pH} 2.5,0.1 \mathrm{mM}$ solution of sodium acetate $(\mathrm{pH} 4.0-6.5)$ for purification [21], and $10 \mathrm{mM}$ solution of Tris- $\mathrm{HCl}(\mathrm{pH} 7.5-9.0)$. The determination of $\mathrm{Km}$ values of phytase was carried out following the method reported by $[22,23]$. On the other hand, the optimal temperature was measured at various temperatures using a $10 \mathrm{mM}$ buffer solution of Tris- $\mathrm{HCl}$; $\mathrm{pH}$ 7.5 mixed with sodium phytate and enzyme reactions. The enzyme reaction was initiated by the addition of the enzyme preparation and $\mathrm{CaCl}_{2}(1 \mathrm{mM})$ for minute. The determination of Km, Vmax, Kcat and Kcat/Vmax was performed using both Michaelis-Menten formula and Lineweaver-Burk plot.

\section{Small scale and high cell density fermentation}

The process of fermentation at small scale was initiated in batch cultivation whereby the transfer of $20 \mathrm{ml}$ preinoculum was performed aseptically to a volume of $200 \mathrm{ml}$ sterile medium in an Erlenmeyer baffled flasks; 500 ml, which contained $V_{\mathrm{R}}=100 \mathrm{ml}$ production medium, at $200 \mathrm{rpm}$ and $28{ }^{\circ} \mathrm{C}$. The desired medium for laboratory scale experimental procedure contained $10 \mathrm{~g} / \mathrm{l}$. On the other hand, high cell density fermentation, P. pastoris was performed in batch mode 
through sterilizing a basal salts medium (2.3 litres) in the NBS BioFlo 415 Benchtop SIP fermentor. The ingredients of BSM medium l L: (g/l) $\mathrm{CaSO}_{4} \cdot 2 \mathrm{H}_{2} \mathrm{O} ; 0.46, \mathrm{~K}_{2} \mathrm{SO}_{4} ; 9.1, \mathrm{MgSO}_{4} \cdot 7 \mathrm{H}_{2} \mathrm{O}$; 7.45, KOH; 2.06, Glycerol; 40, Histidine; 0.4 and $26.7 \mathrm{ml} / \mathrm{l}$ of $\mathrm{H}_{3} \mathrm{PO}_{4}$. The addition of the adjusted $\mathrm{pH}$ of the medium $(\mathrm{pH}=4.8)$ with ammonium hydroxide (25\%) and PTM $_{1}(6 \mathrm{ml})$ trace salts/litre of basal salts medium was carried out aseptically (Clare, et al. 1991). The main ingredients of $\mathrm{PTM}_{1}$ solution: 6 $\mathrm{g} / \mathrm{l}$ of $\mathrm{CuSO}_{4}, 0.08 \mathrm{~g} / \mathrm{l}$ of NaI, $3 \mathrm{~g} / \mathrm{l}$ of $\mathrm{MnSO}_{4}, 0.2 \mathrm{~g} / \mathrm{l}$ of NaMo, $0.02 \mathrm{~g} / \mathrm{l}$ of $\mathrm{H}_{3} \mathrm{BO}_{3}, 0.5 \mathrm{~g} / \mathrm{l}$ of $\mathrm{CoCl}_{2}, 20 \mathrm{~g} / \mathrm{l}$ of $\mathrm{ZnCl}_{2}, 65 \mathrm{~g} / \mathrm{l}$ of $\mathrm{FeSO}_{4}, 5 \mathrm{ml} / \mathrm{l}$ of $\mathrm{H}_{2} \mathrm{SO}_{4}$ and $0.2 \mathrm{~g} / \mathrm{l}$ of Biotin. Various parameters including agitation, aeration, temperature dissolved oxygen, antifoam, carbon source were controlled as shown in table 1.

\section{Repeated Fed batch cultivation with external separator}

The optimization of the repeated fed batch cultivation for the production of phytase at high cell density cultivation in Pichia Pastoris was performed using methanol/sorbitol cofeeding induction technique. The fed-batch cultivation time was converted to repeated fed-batch through harvesting $90 \%$ of the reactor volume, and recharging with fresh BSM medium.

\section{Biomass and total protein analysis}

The control of cell biomass was performed by the method of turbidometric determination or light scattering phenomenon. The Optical density $\left(\mathrm{OD}_{600 \mathrm{~nm}}\right)$ was utilized to represent the level of cells corresponding to the quantity of the scattered light by the culture broth. The turbidity or light scattering was measured at the wavelength of $600 \mathrm{~nm}$ using the spectrophotometer (Hitachi U-2000). The colormetric BioRad protein assay based on the Bradford method was used to determine the total amount of protein in culture liquid. This assay focuses on the color change of Coomassie Brilliant Blue G-250 dye while binding to primarily basic such as arginine and amine group of the protein. The quantity of protein was measured in the format of micro-plate, as determined by the assay kit and the spectrum absorbance peaks recorded at 595 nm using an ELISA reader (Labsystems Multiskan MS).

\section{GC-MS analysis of extract}

The analytical measurement using GC-MS for extract analysis from repeated fed batch fermentation of recombinant Phytase (pPICZ $\alpha$ A-phytase) was performed at high cell density cultivation in Pichia pastoris under methanol/sorbitol co-feeding induction with in methanol. The latter procedure was carried out using a Clarus 500 Perkin Elmer gas chromatography equipped with an Elite- 5 capillary column of phenyl; 5\%, dimethyl polysiloxane; 95\% (30 nm X $0.25 \mathrm{~mm}$ ID X $0.25 \mu \mathrm{mdf}$ ) and mass detector turbo-mass gold which was performed in EI mode. The inert helium gas was used as the carriers at a flow rate of $1 \mathrm{ml} / \mathrm{min}$, and the injector was operated at $290{ }^{\circ} \mathrm{C}$. The oven temperature condition was set as follows; $50{ }^{\circ} \mathrm{C}$ at $8{ }^{\circ} \mathrm{C} / \mathrm{min}$ to $200{ }^{\circ} \mathrm{C}(5 \mathrm{~min})$ at $7{ }^{\circ} \mathrm{C} / \mathrm{min}$ to $290{ }^{\circ} \mathrm{C}(10 \mathrm{~min})$. The data analysis of mass spectrum (GC-MS) was treated by means of the database of National Institute Standard and Technology (NIST), having more than 62,000 patterns. The mass spectrum of the unknown analyte was compared with the spectrum of the known sample stored in the (NIST) library and the name, molecular weight and structure of the components of the test materials were ascertained.

\section{Results and discussion}

During glycerol batch phase, a culture grows whereas the level of dissolved oxygen (DO) lowers and it is in line with the work done by Carly, et al. [24]. When the amount of glycerol in the medium was totally used the DO rose significantly. These results showed the final step of the starting batch phase, and the second step of glycerol $98 \%$ fed-batch was initiated (Figure 1). The method of continuous cultivation was also carried out first to maintain the volume by replacing the old medium by fresh nutrient medium. Its role concentrates on the maintenance of a constant product quality as well to minimize the release of by-products formed during methanol induction alone. The results showed that the repeated fed-batch culture bearing an external separator of phytase formation at high cell density cultivation in Pichia pastoris under methanol/sorbitol co-feeding induction techniques enhanced the activity at about 49 times in comparison to methanol induction alone in a reactor (7 liters) (Figure 2). The volume was maintained and by the time the fermentation process reached a certain stage after which is not effective at all, $90 \%$ of medium was taken off from the vessel and replaced by fresh nutrient medium. In this case no culture was removed until the final stage of the batch, while the decrease in volume led to an increase in the productivity. An effective repeated fed-batch process under methanol/sorbitol feed as carbon source indicated a significant increase in $\mathrm{OD}_{600 \mathrm{~nm}}$ about 5.6 times in comparison with that methanol induction alone. The optimization of phytase formation under methanol/sorbitol co-feeding techniques at lower temperature enhanced the activity at high level [25]. Heterologous expression of phytase in P. pastoris at low temperatures $\left(2{ }^{\circ} \mathrm{C}\right)$ minimized extracellular proteolysis and

Table 1: Parameters for High Cell Density Fermentation of Pichia pastoris (Pichia Fermentation Process Guidelines, Invitrogen).

\begin{tabular}{|c|c|}
\hline Parameter & Reason \\
\hline Temperature $\left(28-20^{\circ} \mathrm{C}\right)$ & To get biomass and protein concentration \\
\hline Dissolved oxygen (> 20\%) & Pichia pastoris needs oxygen to metabolize glycerol and methanol. \\
\hline $\mathrm{pH}(4.8)$ & Important when secreting protein into the medium and for optimal growth. Adjusted using $25 \% \mathrm{NH}_{4} \mathrm{OH} / 88 \% \mathrm{H}_{3} \mathrm{PO}_{4}$ \\
\hline Agitation (200 to $800 \mathrm{rpm}$ ) & Maximizes oxygen concentration in the medium. \\
\hline Aeration ( 0.1 to $1.0 \mathrm{vvm}$ for glass fermenters) & Maximizes oxygen concentration in the medium which depends on the vessel. \\
\hline Antifoam (the minimum needed to eliminate foam) & $\begin{array}{l}\text { PPG was used to a minimum level because excess foam may cause denaturation of phytase and } \\
\text { it also reduces headspace. }\end{array}$ \\
\hline Carbon source (variable rate) & Must be able to add different carbon sources at different rates during fermentation \\
\hline
\end{tabular}




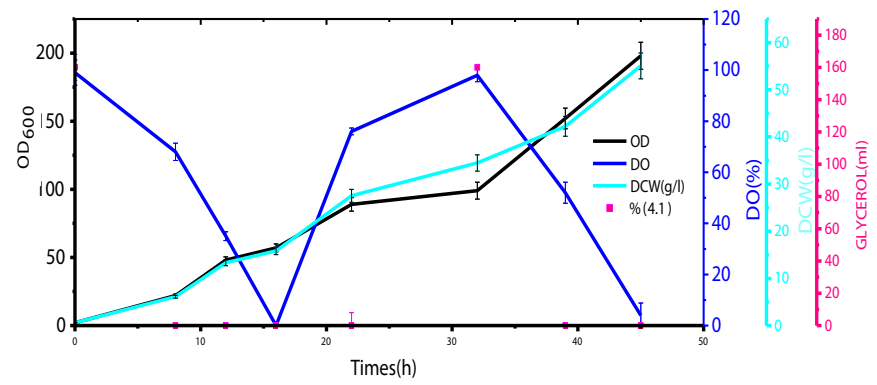

Figure 1: Growth curve analysis during Glycerol Batch and Fed-Bacth Phases.

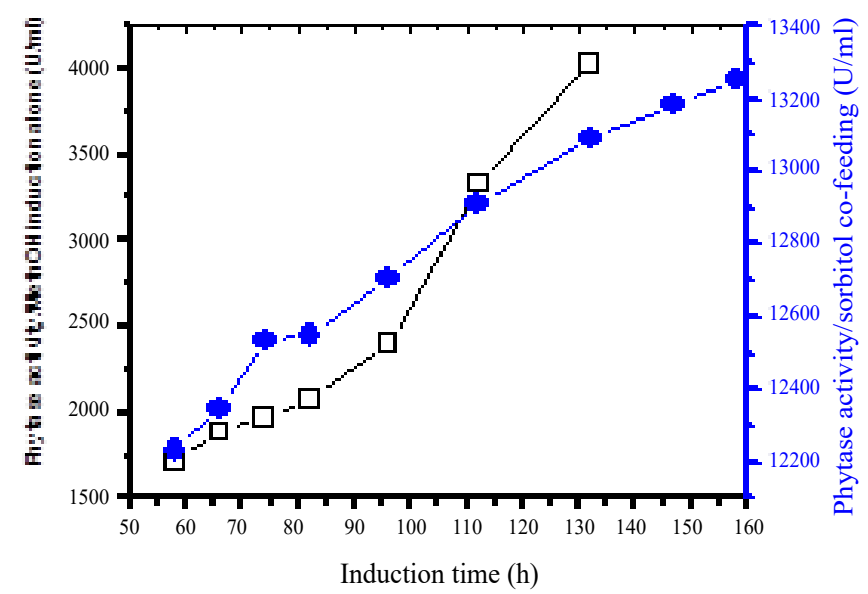

Figure 2: Phytase activity under sorbitol/methanol induction.

enhanced the phytase production [26]. Various phytase gene sequences are available; but the problem is to find a phytase that has a high extracellular activity and other parameters such as temperature stability, wide $\mathrm{pH}$ optima suitable for the commercial use. Nowadays, the methylotrophic yeast P. pastoris is known as an efficient host for high levels of the heterologous expression due to its use of methanol as energy source [27].

Heterologous protein expression by $P$. pastoris in presence of methanol is an extremely oxygen-consuming procedure and induction at lower temperature requires more oxygen supply. Recently, many studies focused on the regulation of methanol use at the gene level but the influence of sorbitol on pAOX1 induction strategy was rarely investigated. This study shows that the recombinant phytase having the optimal temperature of $58{ }^{\circ} \mathrm{C}$ and the optimum $\mathrm{pH}$ of 5.5 (data not shown); at large-scale phytase formation is possible at high specific and thermostability activities. The only difference with some other phytases is having a two $\mathrm{pH}$ optimal $(\mathrm{pH} 2.5$ and $\mathrm{pH} 5.5$ ) and optimal temperature of $6{ }^{\circ} \mathrm{C}$. The evaluation of Pichia pastoris expressed recombinant Phytase enzyme and kinetic properties were carried out. The optimum temperature and $\mathrm{pH}$ of recombinant Pichia pastoris expressed phytase was evaluated over temperature range of 30 to $70^{\circ} \mathrm{C}$ and $\mathrm{pH}$ range of 2 to 9 . The optimal temperature of produced phytase is $58^{\circ} \mathrm{C}$ when the reaction time was 10 minutes, and the optimum pH is 5.5 (Figure 3).
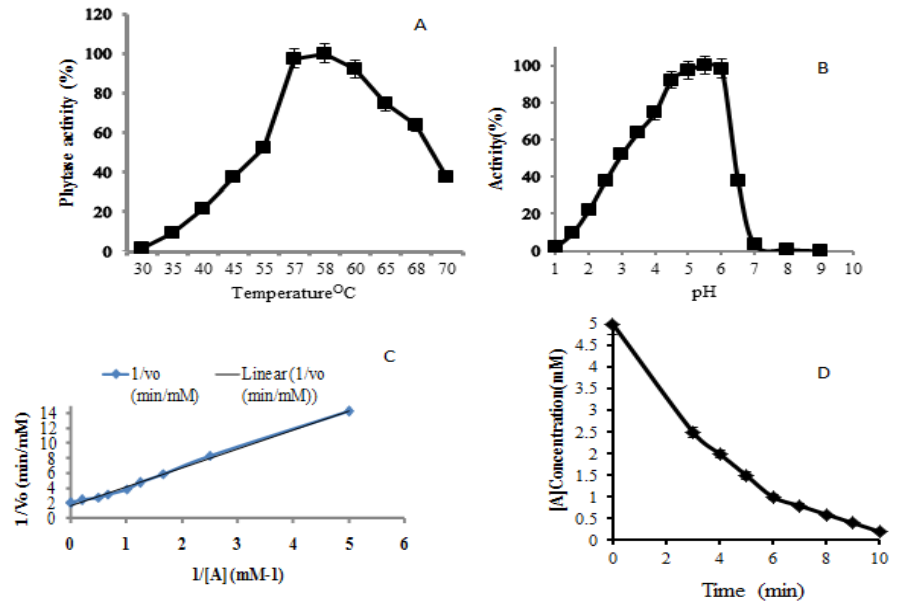

Figure 3: Evaluation of optimum temperature for recombinant Pichia pastoris expressed phytase (A), Evaluation of optimum $\mathrm{pH}$ for recombinant Pichia pastoris expressed phytase (B), Lineweaver Burke plot of recombinant Pichia pastoris expressed phytase $(C)$ and the measurement of half time required for substrate consumption (D)

Phytase enzyme kinetic (Kcat/Km) that shows how efficiently an enzyme converted a substrate into a product was $4.62 * 107 \mathrm{M}^{-1} \mathrm{~s}^{-1}$, whereby the substrate declined from $5 \mathrm{mM}$ to $0.2 \mathrm{mM}$. In this process, $50 \%$ reduction time was reached after 3 minutes of reaction rate which is little different from a theoretical upper limit of-108- 1010-/M.S [28]. An enzyme that works close to this value is termed superefficient and also its reduction time is reached after a period of 2.5 minutes. Other report showed that the expression of an enzyme at lower temperature is applied to promote the yield in P. pastoris, although the fermentation period takes a long time at higher temperature. The results from this report indicates that growing a culture first at 28 ${ }^{\circ} \mathrm{C}$ during Glycerol Batch Phase (GBP) increased the level of biomass prior to induction time. The higher activity was achieved within lesser cultivation time compare to the other studies. Many reports on phytase production showed that phytases with broader substrate generally had low specific activities. Despite considerable economic interest, low yield and high cost of enzyme formation are the main limiting factors in the use of phytase in animal diet. An important idea stresses on the point that sorbitol lowers the accumulation of toxic metabolite-formaldehyde in fermentation process using Pichia pastoris (Mut+) by repressing the formaldehyde dissimilatory pathway [29]. The obtained glycerin was the only byproducts produced during phytase formation; as shown via GC-MS data. On the other hand, the following compounds such as dimethyl-Acetalacetal-of-formaldehyde (methylal), methenamine (Hexamine) were confirmed as by products coming from the reaction of formaldehyde and ammonia. Another compound that was present consists of (S)- $(+)-1,2-$ propanediol which is a product of glycerin and cannot be repressed by the use of methanol only (data not shown). The latter compounds are interfering with phytase production in Pichia pastoris under the induction of methanol. The results obtained from TLC analysis showed that the concentration 
of glycerin obtained under methanol/sorbitol induction technique was smaller than that produced during phytase formation under methanol induction. This indicates that there was too much production of formaldehyde under methanol induction process. Sorbitol as a low degree reductant, nonrepressing source of carbon for $p A O X 1$ and energy supplier reduces oxygen consumption rate by increasing heat or methanol usage so that this alcohol may be strongly utilized for phytase production. Co-feeding of sorbitol minimizes the oxidation flux in the peroxisome, oxygen consumption and heat production as its heat of reaction is highly less than that of methanol. These parameters are of high importance for high cell-density cultures using recombinant $P$. Pastoris strains in case of large scale formation.

\section{Conclusion}

During this study, the mating factor (-factor) preproleader had been considered for the secretory expression of phytase whereby a modified plasmid for phytase expression had been constructed. This process was performed through putting stop a codon before polyhistidine and C-myc epitope tag so that none nature factor from recombinant phytase could be removed. The enzymatic reactions of sorbitol and the impact of glycerin on recombinant protein production are very important tools for portion determination of metabolism that could benefit from future studies. The process of phytase recombinant in presence of sorbitol/methanol is limited by knowledge gaps but this hypothetical process may be discussed by SBO (Systems Biology Ontology) expression omitted process by; Sink metabolism to know how to predict what will occur in organic reaction mechanism and FBA (Flux Balance Analysis) to predict cell growth with different carbon sources. Research to expand our understanding of sorbitol metabolism and bio-chemistry needs to be understood whereby the technique of integrating and establishing biochemical knowledge into computational reconstructions is the future perspectives.

\section{Acknowledgment}

This work was supported by University of Rwanda-College of Science and Technology, Centre for Biotechnology, Anna University, India and REB-Rwanda.

\section{References}

1. Yang J, Zhu L, Cui W, Zhang C, Li D, et al. Increased activity of MdFRK2, a high-affinity fructokinase, leads to upregulation of sorbitol metabolism and downregulation of sucrose metabolism in apple leaves. Hortic Res. 2018; 5: 71.

PubMed: https://pubmed.ncbi.nlm.nih.gov/30534388/

2. Oku T, Nakamura S. Digestion, absorption, fermentation, and metabolism of functional sugar substitutes and their available energy. Pure Appl Chem. 2002; 74: 1253-1261.

3. Tuck C, Ly E, Bogatyrev A, Costetsou I, Gibson P, et al. Fermentable short chain carbohydrate (FODMAP) content of common plant-based foods and processed foods suitable for vegetarian- and vegan-based eating patterns. J Hum Nutr Diet. 2018; 31: 422-435.

PubMed: https://pubmed.ncbi.nlm.nih.gov/29473657/
4. Fredslund F, Otten H, Gemperlein S, Poulsen JCN, et al. Structural characterization of the thermostable Bradyrhizobium japonicum D-sorbitol dehydrogenase. Acta Crystallogr. F Struct Biol Commun. 216; 72: 846-852.

PubMed: https://pubmed.ncbi.nlm.nih.gov/27827356/

5. Rahimi A, Hosseini SN, Karimi A, Aghdasinia H, Mianroodi RA Enhancing the efficiency of recombinant hepatitis $B$ surface antigen production in Pichia pastoris by employing continuous fermentation. Biochem Eng J. 2019 ; 141 : 112-119.

6. Mattanovich D, Sauer M, Gasser B. Yeast biotechnology: teaching the old dog new tricks. Micro Cell Factor. 2014; 13: 34.

7. Niu H, Jost L, Pirlot N, Sassi H, Daukandt M, et al. A quantitative study of methanol/sorbitol co-feeding process of a Pichia pastoris Mut+/ pAOX1-lacZ strain. Micro Cell Factor. 2013; 12: 33.

8. Jin H, Liu G, Ye X, Duan Z, Li Z, et al. Enhanced porcine interferon-a production by recombinant Pichia pastoris with a combinational control strategy of low induction temperature and high dissolved oxygen concentration. Biochem Eng J. 2010; 52: 91-98.

9. Azadi S, Sadjady SK, Mortazavi SA, Naghdi N, Mahboubi A, et al. Bioprocess and downstream optimization of recombinant human growth hormone in Pichia pastoris. Res Pharm Sci. 2018; 13: 222-238. PubMed: https://pubmed.ncbi.nlm.nih.gov/29853932/

10. Canales C, Altamirano C, Berrios J. The growth of Pichia pastoris Mut(+) on methanol-glycerol mixtures fits to interactive dual-limited kinetics: model development and application to optimised fed-batch operation for heterologous protein production. Bioprocess. Biosyst Eng. 2018; 41: 1827-1838.

PubMed: https://pubmed.ncbi.nlm.nih.gov/30196441/

11. Calik P, Hoxha B, Calik G, Ozdamar TH. Hybrid fed-batch bioreactor operation design: control of substrate uptake enhances recombinant protein production in high-cell-density fermentations. J Chem Technol Biotechnol. 2018; 93: 3326-3335.

12. Surendarbabu M, Meenakshisundaram S. High-cell density cultivation of recombinant Pichia pastoris harboring fungal endoinulinase and prebiotics applications of inulo-oligosaccharides. J Environ Biol. 2019; 40: 69-75.

13. Vogl T, Sturmberger L, Fauland PC, Hyden P, Fischer JE, et al Methanol independent induction in Pichia pastoris by simple derepressed overexpression of single transcription factors. Biotechnol Bioeng. 2018; 115: 1037-1050.

PubMed: https://pubmed.ncbi.nlm.nih.gov/29280481/

14. Wang J, Wang X, Shi L, Zhang Y, Zhou X, et al. Reduced methanol input induces increased protein output by AOX1 promoter in a trans-acting elements engineered Pichia pastoris. J Ind Microbiol Biotechnol. 2018; 45: 25-30.

PubMed: https://pubmed.ncbi.nlm.nih.gov/29230578/

15. Luo G, Tian J, Huang $\mathrm{H}, \mathrm{An} \mathrm{L}$. Improving heterologous expression of porcine follicle-stimulating hormone in Pichia pastoris by integrating molecular strategies and culture condition optimization. Appl Microbiol Biotechnol. 2018; $102: 8867-8882$.

PubMed: https://pubmed.ncbi.nlm.nih.gov/30136206/

16. Troshagina DS, Suleimanova AD, Itkina DL, Sharipova MR. Cloning of Phytase Genes from Pantoea Sp 3.5.1 and Bacillus ginsengihumi M2.11 in Pichia pastoris. Bio Nano Sci. 2018; 8: 1045-1053.

17. Cayetano-Cruz M, Perez de los Santos Al, Garcia-Huante $Y$, Santiago-Hernandez A, Pavon-Orozco P, et al. High level expression of a recombinant xylanase by Pichia pastoris cultured in a bioreactor with methanol as the sole carbon source: Purification and biochemical characterization of the enzyme. Biochem Eng J. 2016; 112: 161-169.

18. Chen L, Mohsin A, Chu J, Zhuang Y, Liu Y, et al. Enhanced Protein Production by Sorbitol Co-feeding with Methanol in Recombinant Pichia pastoris Strains. Biotechnol Bioprocess Eng. 2017; 22: 767-773.

19. Liu WC, Gong T, Wang QH, Liang X, Chen JJ, et al. Scaling-up 
fermentation of Pichia pastoris to demonstration-scale using new methanol-feeding strategy and increased air pressure instead of pure oxygen supplement. Sci Rep. 2016; 18439.

PubMed: https://pubmed.ncbi.nlm.nih.gov/26790977/

20. Burgard J, Valli M, Graf AB, Gasser B, Mattanovich D. Biomarkers allow detection of nutrient limitations and respective supplementation for elimination in Pichia pastoris fed-batch cultures. Microb Cell Fact. 2017; 16: 117.

21. Promdonkoy $P$, Tang $K$, Sornlake $W$, Harnpicharnchai $P$, Kobayash RS, et al. Expression and characterization of Aspergillus thermostable phytases in Pichia pastoris. FEMS Microbiol Lett. 2009; 290: 18-24. PubMed: https://pubmed.ncbi.nlm.nih.gov/19025560/

22. Ribeiro Correa TL, de Queiroz MV, de Araujo EF. Cloning, recombinant expression and characterization of a new phytase from Penicillium chrysogenum. Microbiol Res. 2015 ; 170 : 205-212.

PubMed: https://pubmed.ncbi.nlm.nih.gov/25023696/

23. Zhao DM, Wang $M, M u X J$, Sun ML, Wang $X Y$. Screening, cloning and overexpression of Aspergillus niger phytase (phyA) in Pichia pastoris with favourable characteristics. Lett Appl Microbiol. 2007; 45: 522-528.

PubMed: https://pubmed.ncbi.nlm.nih.gov/17958557/

24. Carly F, Niu H, Delvigne F, Fickers P. Influence of methanol/sorbitol co-feeding rate on pAOX1induction in a Pichia pastoris Mut+ strain in bioreactor with limited oxygen transfer rate. J Ind Microbiol Biotechnol. 2016; 43: 517-523.

PubMed: https://pubmed.ncbi.nlm.nih.gov/26790417/

25. Xie Z, Fong WP, Tsang PWK. Engineering and optimization of phosphate-responsive phytase expression in Pichia pastoris yeast for phytate hydrolysis. Enzyme Microb Technol. 2020.

PubMed: https://pubmed.ncbi.nlm.nih.gov/32423670/

26. Karbalaei M, Rezaee SA, Farsiani H. Pichia pastoris: A highly successful expression system for optimal synthesis of heterologous proteins. J Cell Physiol. 2020.

PubMed: https://www.ncbi.nlm.nih.gov/pmc/articles/PMC7228273/

27. Prielhofer R, Cartwright SP, Graf AB, Valli M, Bill RM, et al. Pichia pastoris regulates its gene-specific response to different carbon sources at the transcriptional, rather than the translational, level. BMC Genomics. 2015; 16: 167.

PubMed: https://pubmed.ncbi.nlm.nih.gov/25887254/

28. Singh $P$, Islam Z, Kohen A. Examinations of the chemical step in enzyme catalysis. Methods in Enzymol. 2016; 287-318.

PubMed: https://pubmed.ncbi.nlm.nih.gov/27498642/

29. Liu W, Zhou F, Xia D, Shiloach J. Expression of multidrug transporter Pglycoprotein in Pichia pastoris affects the host's methanol metabolism. Microb Biotechnol. 2019; 12: 1226-1236. PubMed: https://pubmed.ncbi.nlm.nih.gov/31131547/ 